\title{
THREE NEW SPECIES OF PIPER (PIPERACEAE) FROM THE GUIANAS
}

\author{
A.R.A. GÖRTS-VAN RIJN ${ }^{1} \&$ R. CALLEJAS POSADA ${ }^{2}$
}

\begin{abstract}
SUMMARY
Three new species of Piper from the Guianas and adjacent areas are described: Piper aulacospermum Callejas, P. ciliomarginatum Görts \& Christenh. and P. remotinervium Görts. The differences between P. aulacospermum and P. bartlingianum (Miq.) C.DC., both belonging to subg. Ottonia, are given as well as notes on all three species.
\end{abstract}

Key words: Piperaceae, Piper, Guianas.

\section{INTRODUCTION}

The plant family Piperaceae occurs in the neotropics from Mexico through Central America and the West Indies to South America. The family is well represented in the Guianas by the genera Peperomia (29 species) and Piper (58 species). Some species are restricted to the Guianas or even to only one of the three geographical entities (11 pipers and 4 peperomias). In the process of preparing a treatment of the family for the Flora of the Guianas project several Piper collections could not be identified. They represent three new species, which are published and illustrated here.

\section{Piper aulacospermum Callejas, spec. nov. - Fig. 1}

Piperi bartlingiano (Miq.) C. DC. similis sed differt inflorescentiis $0.5-4.5 \mathrm{~cm}$ (nec 7-16 $\mathrm{cm}$ ) longis, pedunculis puberulis (nec glabris), floribus congestis (nec dispersis), seminibus globosis, 3-3.5 mm diam. (nec obovoideis, 2-3 mm longis). - Typus: Mori \& Pennington 18087, French Guiana, near Saül, la Fumée Mt (holo NY).

Small shrub 1-2.5 m tall, sparingly branched. Stem striate or canaliculate, glabrous. Prophyll 2-4 cm long, glabrous, caducous. Petiole 7-13 mm long, glabrous; deeply vaginate at the base; blade thick chartaceous, not scabrous, not conspicuously glandulardotted, oblong or elliptic-oblong, 13-16.5 by (3.5-) 4-6.5 cm, apex abruptly longacuminate, base equally attached to the petiole or almost so, acute, glabrous; pinnately veined, secondary veins $8-12$ per side, sulcate above, prominent below, anastomosing well within the margin, originating throughout the whole length of the primary vein, tertiary veins widely reticulate. Inflorescence erect, white, becoming green; peduncle $10 \mathrm{~mm}$ long, minutely pubescent; spike with young flowers $0.5-1 \mathrm{~cm}$ long by $0.1-0.2$

1) Nationaal Herbarium Nederland, Utrecht University branch, Heidelberglaan 2, 3584 CA Utrecht, The Netherlands.

2) Instituto de Biologia, Universidad de Antioquia, AA1226 Medellin, Colombia. 


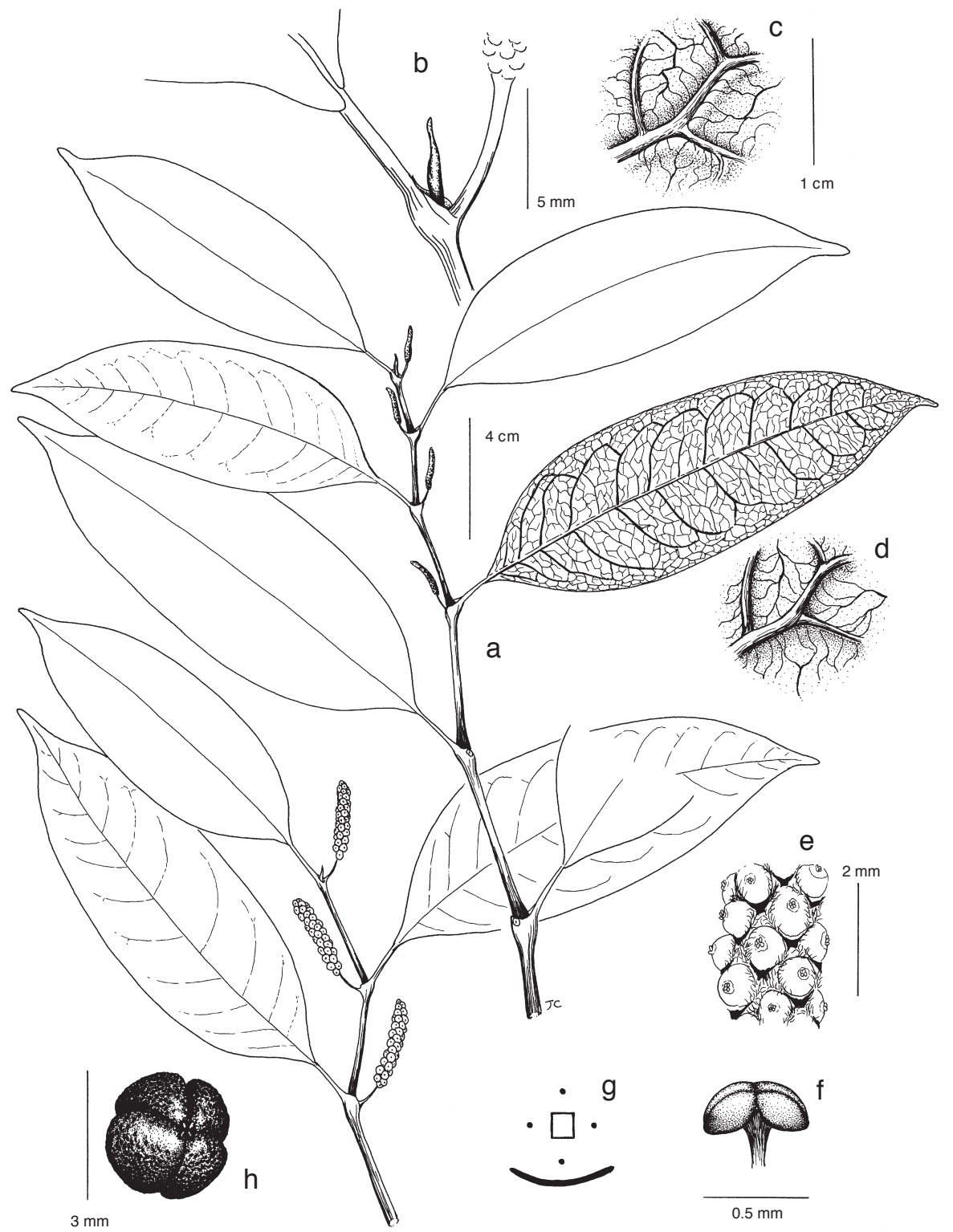

Fig. 1. Piper aulacospermum Callejas. a. Habit, showing sympodial branches with inflorescences at anthesis and fruit; b. detail of leaf base and prophyll; c. leaf veins, view from above; d. leaf veins, view from below; e. young fruits; f. anther; g. floral diagram; h. seed (all: Mori \& Pennington 18087). Drawn by J. Colorado, HUA. 
$\mathrm{cm}$ in diam., in fruit $2.5-4.5$ by $0.3-0.45 \mathrm{~cm}$, not apiculate; floral bracts saccate or galeate, glabrous centrally and densely fimbriate; flowers densely congested; anthers reniform. Fruits globose, 4-sulcate, truncate at apex, 3-4.5 mm in diam., glabrous; persistent stigmas 4 , globose, sessile; seeds globose, deeply sulcate with 4 grooves, $3-3.5 \mathrm{~mm}$ in diameter.

Distribution - Endemic to the Guianas. In low land, non-flooded forest; altitude $200-450 \mathrm{~m}$.

Note - The four staminate flowers, the deeply lobed seeds and the pinnately veined leaves of this species are characteristic of those species belonging to subg. Ottonia. Most species of subg. Ottonia are restricted to the eastern Atlantic forests of Brazil, with less than a dozen species occurring elsewhere in central and northern Amazonia. In that region the most common taxon of subg. Ottonia is the widely distributed Piper bartlingianum, likely the most closely related species to $P$. aulacospermum. The taxa differ clearly on the basis of the globose fruits of P. aulacospermum (vs obovoid in $P$. bartlingianum), which are truncate at apex and distinctly deeply grooved; the inflorescences that are $(0.5-) 2-4.5 \mathrm{~cm}$ long (vs $7-16 \mathrm{~cm}$ in $P$. bartlingianum) and the puberulous (vs glabrous) peduncles.

2. Piper ciliomarginatum Görts \& Christenh., spec. nov. - Fig. 2

Frutex 1-3 m alta. Caulis glaber. Petioli foliorum inferiorum 4-30 mm longi, foliorum superiorum 0-3 mm longi, glabri, ad basim laminae vaginati vel alati. Folia non scabri, creberrime glandulo-punctata, elliptico-ovata, 13-22 cm longa, 6-11 cm lata, marginibus ciliatis, apice acuta vel acuminata, basi aequali vel inaequali latere altero ad $4 \mathrm{~mm}$ breviore quam alterum, acuta, obtusa, rotundata vel subcordata, supra et subtus praeter marginem ciliatam, glabra, venis secundariis utrinque 4-6, e dimidio inferiore costae orientibus, venis tertiaribus reticulatis. Inflorescentiae erectae, $8-16 \mathrm{~mm}$ longe pedunculatae, spicis non apiculatis, albis, bracteis floralibus dense fimbriatis. Infructescentiae pendentes, 7-8 $\mathrm{cm}$ longae. Fructus trigoni, $0.4 \mathrm{~mm}$ diametro metuentes, glabri, stigmatibus persistentibus 3 ornati. - Typus: Henkel 2231, Guyana, Kaiteur National Park (holo U; iso US); para: Henkel 2166, 2185.

Shrub to 1-3 m tall. Stem glabrous. Prophyll to $2.5 \mathrm{~cm}$ long, glabrous. Petiole of lower leaves 4-30 mm long, of upper leaves 0-3 mm long, glabrous, vaginate or winged over the whole length; blade not scabrous, densely glandular-dotted, elliptic-ovate to broadly ovate, $13-22$ by $6-11 \mathrm{~cm}$, margin ciliate, apex acute to acuminate, base equally or somewhat unequally attached to the petiole over $0-4 \mathrm{~mm}$, acute, obtuse, rounded or subcordate; glabrous except for ciliate margin; pinnately veined, secondary veins 4-6 per side, originating from lower half of primary vein, flat above and below, tertiary veins reticulate. Inflorescence erect; peduncle 8-16 mm long, glabrous; spike 2-8 $\mathrm{cm}$ long, not apiculate, white; floral bracts densely marginally fringed. Infructescence pendent, $7-8 \mathrm{~cm}$ long, $3 \mathrm{~cm}$ thick, green; fruits trigonous, $0.4 \mathrm{~mm}$ wide, glabrous; persistent stigmas 3, sessile.

Distribution - Venezuela, Guyana and Suriname; altitude to $850 \mathrm{~m}$.

Note - The ciliate margin marks the species. It differs from ciliate margined Piper augustum Rudge in the number of secondary veins 3-7 (vs 10-16) originating from the lower half of the primary vein (vs throughout). The choice of the name is obvious from the ciliate margin. 

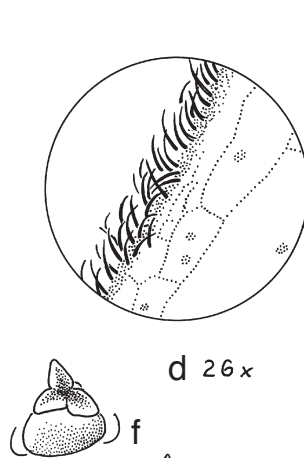

d $26 x$
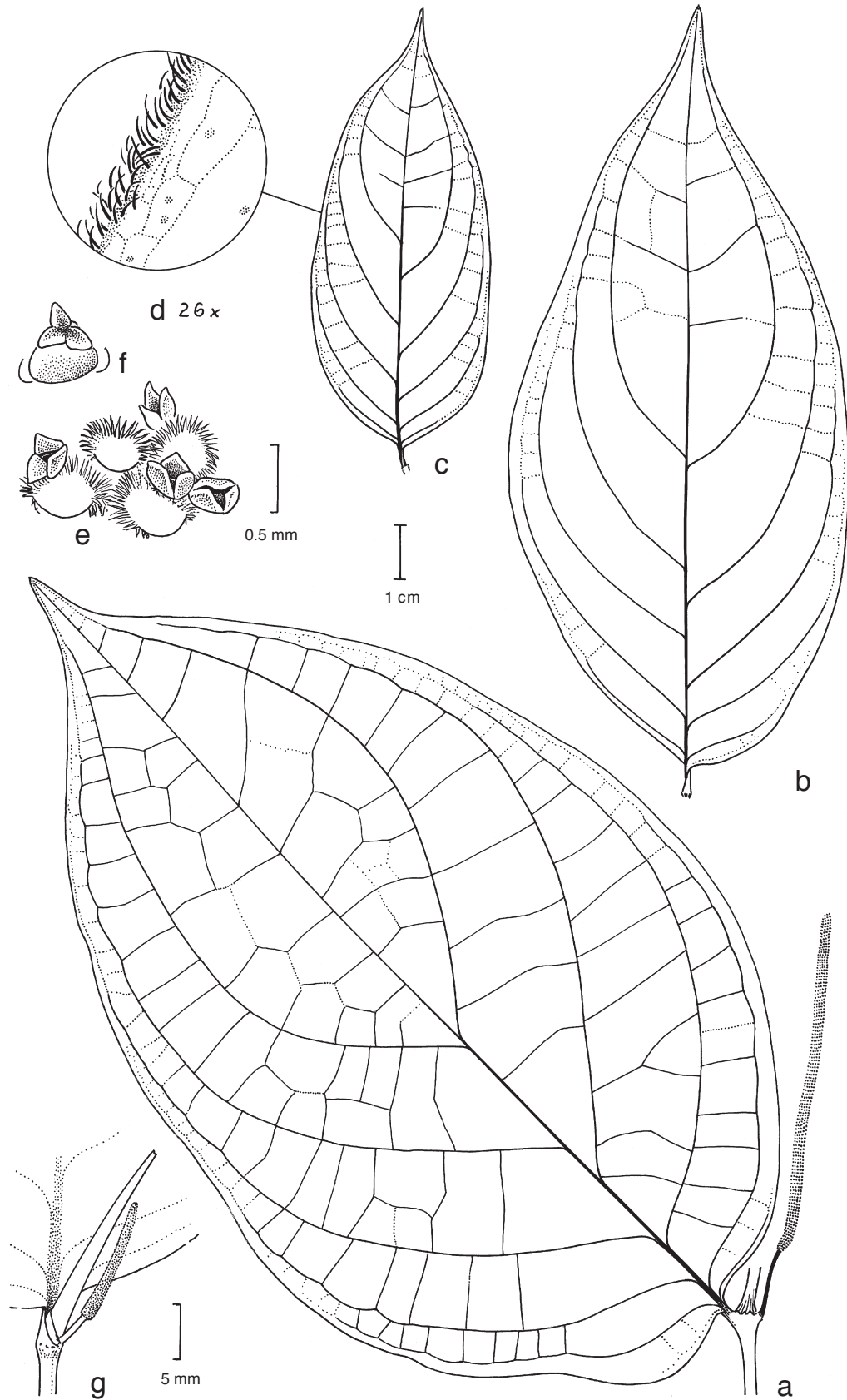

b

Fig. 2. Piper ciliomarginatum Görts \& Christenh. a. Apex of branch with leaf, withering prophyll and young spike; b, c. showing variation in leaf shape; d. detail of leaf margin; e. detail of spike showing floral bracts and young fruits with persistent stigmas; f. young fruit; g. tip of young branch showing leaf base, prophyll and developing spike (a, b, g: Henkel 2231; c, d, f: Henkel 2166; e: Henkel 2185). Drawn by H. Rypkema, U. 


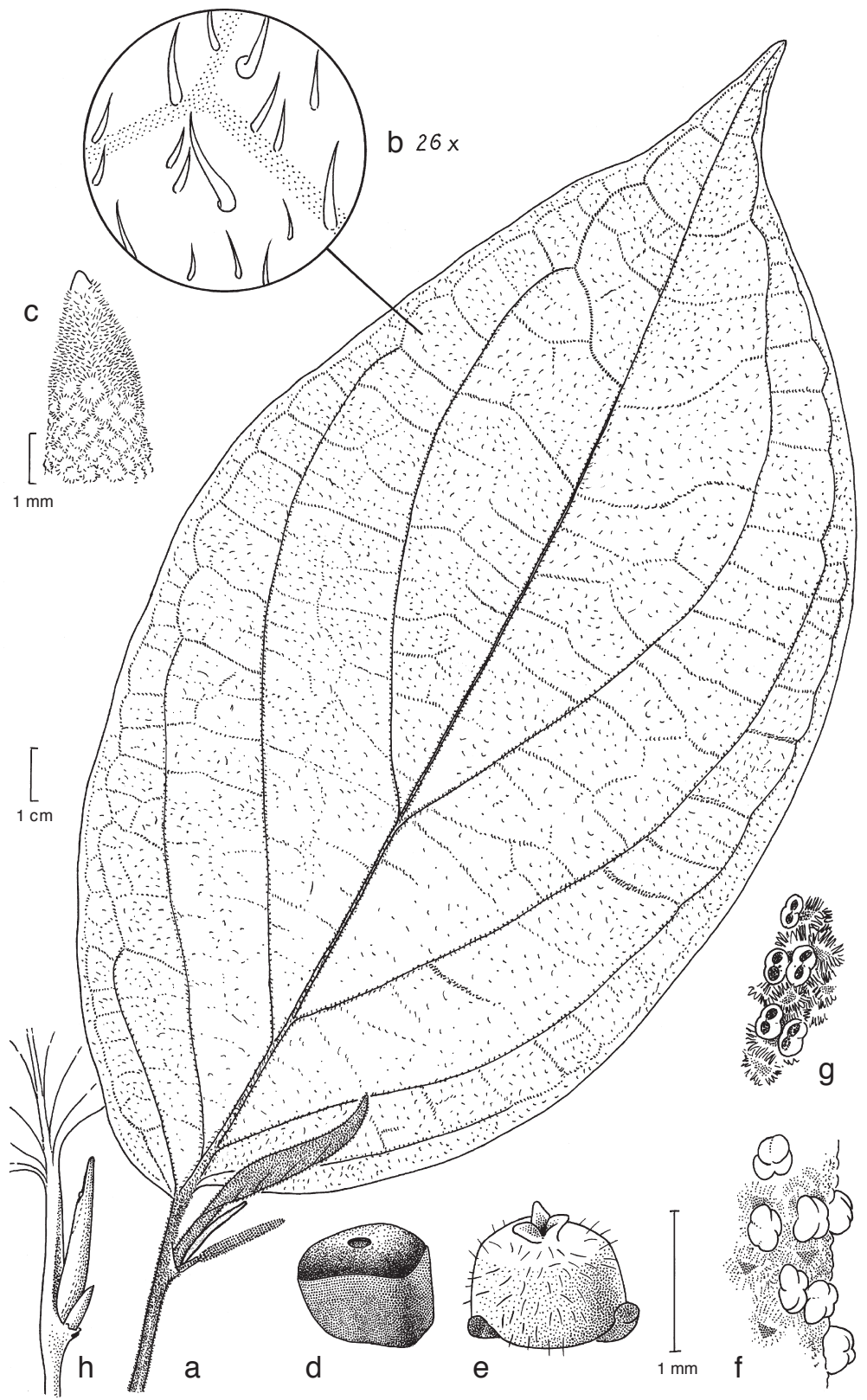

Fig. 3. Piper remotinervium Görts. a. Apex of branch with leaf, developing young branch tip, prophyll and immature spike; $b$. indument on leaf surface; c. apiculate tip of spike; d. fruit as seen in dried collection; e. fruit with persistent stigmas and remnants of stamens; f. detail of spike showing young anthers; g. detail of spike with open anthers between fimbriate floral bracts; $h$. apex of young branch showing leaf base, developing tip of branch and prophyll ( $2 \times$ natural size) (a-c: Feuillet 530; d: De Granville 4444; e: De Granville 13110; f. g: McDowell 2225; h: Cremers 15083). Drawn by H. Rypkema, U. 
3. Piper remotinervium Görts, spec. nov. - Fig. 3

Frutex 1-3.5 m alta, caule et ramulis petiolisque dense pubescentibus. Petioli $15-30 \mathrm{~mm}$ longi. Folia late ovata, $17-30 \mathrm{~cm}$ longa, $10-17 \mathrm{~cm}$ lata, scabridiuscula (sicca), apice acuminata, basi subcordata vel obtusa, ad petiolem aequali vel inaequali latere altero ad $7 \mathrm{~mm}$ breviore quam alterum, non manifeste glanduloso-punctata, supra et subtus pubescentes; venis secundariis utrinque 5-7, e dimidio inferiore costae orientibus, subtus prominentibus, venulis tertiariis transversalibus, late reticulatis. Inflorescentiae rectae vel horizontaliter patentes, pedunculis pubescentibus, $15-20 \mathrm{~mm}$ longis; spicis haud apiculatis, $10-20 \mathrm{~cm}$ longis. Bracteae florales dense fimbriatae. Fructus trigoni (in sicco), globosi, paulo exserti quando maturi stigmatibus persistentibus sessilibus. - Typus: De Granville et al. 4474, Guiana gallica, Saül, route de Bélizon, pk 7, Eau Claire (holo U; iso CAY, P).

Shrub or treelet, to $1-3.5 \mathrm{~m}$ tall. Stem and branches densely pubescent (one of the Guyanan collections is only sparsely pubescent). Prophyll to $1 \mathrm{~cm}$ long, glabrous. Petiole 15-20 mm long, densely pubescent; blade somewhat scabrous when dried, not conspicuously glandular-dotted, broadly ovate (or ovate in De Granville et al. 7435), $17-30$ by $10-17 \mathrm{~cm}$, apex acuminate, base equally or unequally attached to the petiole over $0-3(-7) \mathrm{mm}$, subcordate or somewhat obtuse, pubescent on both surfaces, the veins more densely so; pinnately veined, secondary veins $5-7$ per side, originating from lower half of the primary vein, prominent below, tertiary venation widely reticulate, veinlets almost transverse. Inflorescence erect or horizontally oriented; peduncle 15-20 mm long, pubescent; spike 10-20 cm long, slightly apiculate, creamish white to green; floral bracts densely marginally fringed. Fruits globose (trigonous in dried collections), somewhat exserted when mature, hirsute; stigmas sessile.

Distribution - Guyana, French Guiana and Brazil (Pará); in (dense) forest; altitude 20-300 m. 30 collections studied (GU: 2; FG: 28).

Notes - Piper remotinervium is easily distinguished from other taxa in the genus by the combination of trigonous hirsute fruits, floral bracts with a short hirsute fimbriate margin, the uppermost pair of veins arising below the mid portion of the leaf and the presence of erect, rigid trichomes on both sides of the leaf. It should be noted that in some specimens the trichomes on the leaf lower surface tend to have different lengths (e.g. De Granville et al. 13926).

The specimens here assigned to $P$. remotinervium previously had erroneously been identified as P. tectonifolium (Kunth) C.DC. However, the latter species is endemic to the Atlantic forests of northern South America, where it grows in open non-flooded areas or forest margins.

The name remotinervium means 'veins far apart', which is characteristic for the species.

\section{ACKNOWLEDGEMENTS}

We are grateful to the curators of the herbaria CAY, HUA, NY, P, U and US for enabling us to study their collections. Many thanks are due to M. Christenhusz, who as a student in plant systematics assisted the senior author to finish her studies on Guianan Piperaceae in Utrecht, and to H. Rypkema and J. Colorado who made the illustrations. We thank L. Westra for embellishing the Latin and English wording of this publication. 


\section{IDENTIFICATION LIST}

Cremers 15083: 3 .

De Granville et al. 4444: 3; 4474: 3; 7435: 3; 9052: 3; 9128: 3; 13110: 3; 13926: 3.

Feuillet 530: $3 ; 1211: 1 ; 2233: 3$.

Hahn 4669: 2 - Henkel 2166: 2; 2185: 2; 2231: 2; 4881: 1 - Hoff 5540: 3.

Irwin et al. 54998: 2.

Liesner 22580: 2.

Marshall \& Rombold 138:1 - McDowell 2225: 3 - Mori et al. 14919: 1; 15399: 1; 15491:1; 18087: 1; 21994: 3 .

Pipoly 10632: 3 .

Van Donselaar 2298: 1. 